\title{
CAN COPPER AND ZINC IN DIFFERENT CHEMICAL FORMS CAN IMPROVE IRON DEFICIENT IN PHASEOLUS PLANT
}

\author{
$*$ Z, A. Salama ${ }^{1}$ \\ Prof. \\ M. M.El Fouly ${ }^{2}$ \\ Prof.
}

${ }^{1}$ Dep. Plant Biochem. National Res Centre, 33 El-Bohouth St., Dokki, Giza, P.O. 12622 - Egypt

${ }^{2}$ Dep. Fertiliz. Techno. National Research Centre, 33 El-Bohouth St., Dokki, Giza, P.O. 12622 - Egypt zeinabsalama70@ hotmail.com

\section{ABSTRACT}

This study aims to compare between the effects of different chemical forms of copper and zinc in ionic form (CuSO4), (Zn SO4) and in chelated form (Cu (II) HEDTA and Zn (II) HEDTA], whereas, HEDTA is $\mathrm{N}$-(hydroxyethyl) ethylenediamine triacetic acid, applied at micromolar concentrations of Phaseolus Vulgaris (Nebraska)plants grown hydroponically under conditions of iron deficiency (- Fe) . Two plant variants $(-\mathrm{Fe}+2 \mu \mathrm{M} \mathrm{Cu} 2+)$ and $(-\mathrm{Fe}+20 \mu \mathrm{M} \mathrm{Zn2+)}$ were examined. The results showed the greening of plants in new leaves, which confirmed the results of chlorophyll after treatment with diamine triacetic acid (HEDT). The results also showed a change in the reduction activity of the plasma membrane of the root system after treatment with ionic or chelated copper in plants growing under conditions (iron - and (+ iron)), with an increase in root PMRA with an increase in the enzymatic activity of both Fe-Chelate Reductase Activity, Regard to the increase of cell compounds, presence of $20 \mu \mathrm{M}$ of $\mathrm{Zn}$ developed the action of the protein superoxide dismutase and peroxidase activities.

Keywords: Fe deficient- Fe chelates reductase activity- $\mathrm{Cu}^{2+}, \mathrm{Zn}^{2+}-\mathrm{Cu}-$ HEDTA-Zn-HEDTA.

هل يمكن للنحاس والزنك بأشكال كيميائية مختلفة تحسين نقص الحديد في نبات الفاصوليا؟

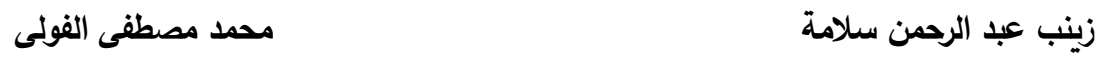

قسم الكيمياء الحيوية النباتية -المركز القومى للبحوث - 33 شارع البحوث - دقى -جيزة -صندوق البريد 332622 -

قسم تكنولوجيا التسميد - المركز القومى للبحوث - 33 شارع البحوث - الدقى - الجيزة - صندوق برئهي

تهاف الدراسة إلى المقارنة بين الصور الكيميائية المختلفة لكل من الزنك والنحاس سواء فى الصورة الايونية ( كبريتات النحاس وكبريتات

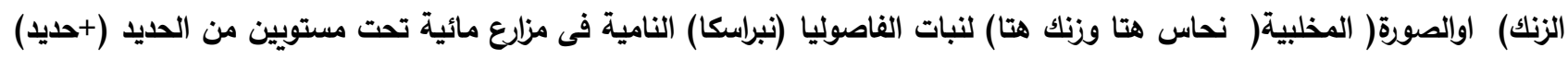

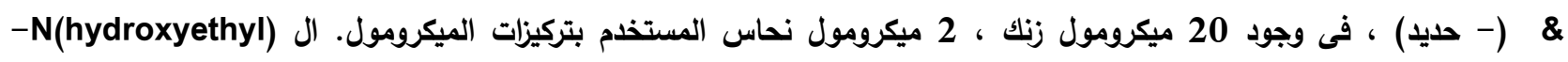
ethylenediamine triacetic acid HEDT معالجة النباتات بال النحاس المخلبى تحت ظروف نقص الحديد .كذلك اوضحت النتائج تغيرات فى النشاط الاختزالى للفشاء البلازمى الإنى

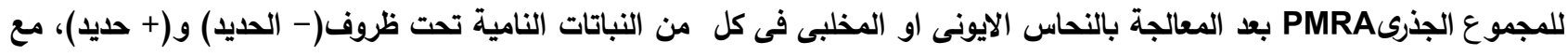

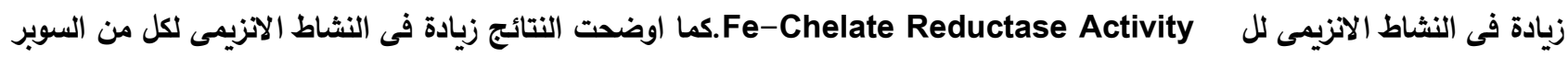
اوكسيد ديسميويز والبيرواكسيليز مع 20 ميكرومول زنك سلفات.

الكلمات المفتاجية: نقص الحديد، نثاط اختزال الحديديك،نحاس ايونى، زنك ايونى، نحاس مخلبى ، زنك مخلبى، الفاصوليا 


\section{INTRODUCTION}

Copper and iron are important plant micronutrients with root redox mechanisms and directed their mobilization, uptake, and translocation (2). The regulation of Fe and $\mathrm{Cu}$ homeostasis in plant cells under sub-optimal growth conditions is extremely important for plant productivity. Iron deficiency is a limiting factor for plant growth and yield and is spread in different crops, mainly in alkaline and calcareous soils, due to the insolubility of iron oxides and hydroxides $(31,38,40)$. Additionally, Feinsufficiency under different conditions of stress in soils can be combined with increased level of copper moving in plant tissues by fungicide (1, 7, and 13). Ferricchelate reductase is the most studied redox enzyme; it is an integral membrane protein belonging to a family of flavoproteins that transfer electrons from cytosolic NADH to extracellular electron acceptors via FAD and heme groups $(15,27)$. Besides a high induction of ferric-chelate reductase activity (FeChRA) in roots of iron-deficient plants, iron deficiency dicotyledonous plants such as phaseolus develop various adaptive morphological and biochemical mechanisms which improve iron acquisition in soil solutions (17). The main adaptive process includes a strong increase in plasma membrane (PM) ferric-chelate reductase activity by roots accompanied by enhanced proton release needed for the reduction of Fe (III) to more soluble Fe (II) in the apoplast. Acidification of the rhizosphere is fulfilled by activation of PM proton pump and the biosynthesis of specific ferrous transporters at PM is accelerated $(10,11,15,27)$. It was set up that iron deprivation brought to expanded substance of copper in roots (22), but on the other hand it has been demonstrated that ionic copper created the capacity of FeChRA of iron-deficient plants $(3,28,31)$. The aim of the present study was to examine if copper and zinc in different chemical forms ionic or chelated can ameliorate iron deficient in phaseolus plants?

\section{MATERIALS AND METHODS}

Plant growth conditions

The experiment was carried out at Fertilization Technology Deportment,National Research centre, Cairo, Egypt. Seeds of phaseouls (Nebraska) were washed and soaked for several hours in tap water.The germination was carried out in plastic dishes at $(301 \mathrm{~K})$ in dark. Three days -old seedlings were put to grow in plastic pots filled with one tenth concentration nutrient solution $\mathrm{pH}$ (6.0)according to (21) .The seedlings were grown in a a controlled chamber (Snijder Scientific )under $12 \mathrm{~h}$ light at PPFD of 120 micromol m-2 s-1 provided by fluorescent tubes 12-h night,60\% $\mathrm{RH}$,at $18 \mathrm{C} 0$ day/6c0 night temperature nutrient Solutions was changed every two days and supplemented with 20micromol Fe (iii) HEDTA and 0.2micromol of $\mathrm{Cu}$ SO4 for control (+ Fe)plants according to (8). After two days the plants were divided into two variants $(+\mathrm{Fe})$ and ( - Fe).Each treatment treated with $\mathrm{Cu}+2$ and $\mathrm{Zn}+2$ in ionic and chelated forms. Plants were harvested at twelfth days old, growth ,pigment content,Fe-chelate reductase activity,antioxidant enzymes were determined.

Treatment of plants with ionic and chelated copper and zinc: Four-day-old seedlings were treated with different concentrations of $(2 \mu \mathrm{M}) \mathrm{CuSO}_{4}$ or $2 \mu \mathrm{M} \mathrm{Cu}$ (II) HEDTA; and $(20 \mu \mathrm{M}) \mathrm{Zn} \mathrm{SO}_{4}$ or Zn HEDTA. The complexes $\mathrm{Cu}$ (II) HEDTA and $\mathrm{Zn}$ (II)HEDTA were prepared as stock solutions, $\mathrm{pH} 6.0$ with Tris-KOH according to (7). Solutions were changed every other day for the twelfth days.

Measurement of ferric- reductase activity by intact roots

Fe (III) HEDTA (as a more natural substrate) was used as electron acceptors. The incubation medium for reductase activity measurements contained $0.1 \mathrm{mM}$ $\mathrm{CaCl}_{2}, 0.15 \mathrm{mM} \mathrm{Fe}(\mathrm{III})$ or $\mathrm{Cu}$ (II) complex and $0.3 \mathrm{mM}$ BPDS in a final volume of 10 or $15 \mathrm{ml}$ in dark vessels at pH 5.5 for $\mathrm{Fe}$ (III) ChRA as described previously $(5,6)$. The reductase activity of intact roots was expressed in $\mu$ mol Fe (II) $\cdot g-1$ root $\mathrm{FW} \cdot \mathrm{h}^{-1}$ was performed according to (31).

\section{Extraction and Estimation of Chlorophyll}

One plant per replicate was used for chlorophyll determination. Prior to extraction, fresh leaf samples were cleaned with deionized water to remove any surface contamination. Chlorophyll extraction was carried out on fresh fully expanded leaf material; $1 \mathrm{~g}$ leaf sample was ground in $80 \%$ acetone using a pestle and mortar. The absorbance was measured with a UV/Visible spectrophotometer (Pye Unicam SP6-550, UK) and chlorophyll concentrations were calculated using the equation proposed by (24).

\section{Extraction of cytosolic fraction}

Five gram of plant material was excised and homogenized in $10 \mathrm{ml}$ of ice-cold grinding buffer containing 0.4 M sucrose and $25 \mathrm{mM}$ Tris ( $\mathrm{pH}$ 7.2). The homogenate was passed through 4 layers of Gauze and centrifuged at $12,000 \times \mathrm{g}$ for $15 \mathrm{~min}$ at $(277 \mathrm{~K})$. The resulting supernatant was used for determination of enzyme activities

Superoxide dismutase (SOD) (EC 1.15.1.1) activity was defined by its power to suppress the formation of nitroblueformazan from NBT according to (20).

Peroxidase (POD) (EC 1.11.1.9) activity was measured according to (4).

\section{Statistical analysis}

Data were statistically analyzed using statistical package data according to (35).

\section{RESULTS AND DISCUSSION}

\section{Symptoms of iron-deficient}

The developing plants in a 12-day feeding solution without iron and $2 \mu \mathrm{mol}$ copper ions were shown to be yellow in the first and second leaves compared to control. Data presented in (Figure 1) show that phaseolus plants are grown for 12 days without iron in the nutrient solution developed moderate chlorosis on the first and second leaves (Figure 1), with chlorophyll reduction in comparison with $(+\mathrm{Fe})$ plants (Table 1$)$. The additional of $2.00 \mu \mathrm{M}$ cupric ions in solutions of Fe-deficient plants gave very strong chlorosis (Figure 1). The same or even higher decline in chlorophyll concentration of Fe-deficient plants was found with 20 $\mu \mathrm{M} \mathrm{Zn}$-ions supply. Chelated forms of $\mathrm{Cu}$ and $\mathrm{Zn}$, applied continuously on Fe-deficient plants kept the pigment content to a higher level in comparison with the control $(-\mathrm{Fe})$ plants (Table 1$)$. In spite of very strong 
chlorosis invariant $(-\mathrm{Fe}+\mathrm{Cu})$ before treatment with $\mathrm{Cu}$ (II) HEDTA treatment of phaseolus delayed leaf greening. Using the same experimental for the other variant $(-\mathrm{Fe}+\mathrm{Zn})$ with pale-yellow first leaf, some differences after application of cupric- and zinc-chelates were received (Figure1). The highest positive effect on leaf greening was achieved with application of $\mathrm{Cu}$ (II)HEDTA supply which produced smaller, but still positive effect. While, Zn(II)HEDTA supply did not ameliorate leaf chlorosis (Figure 1).
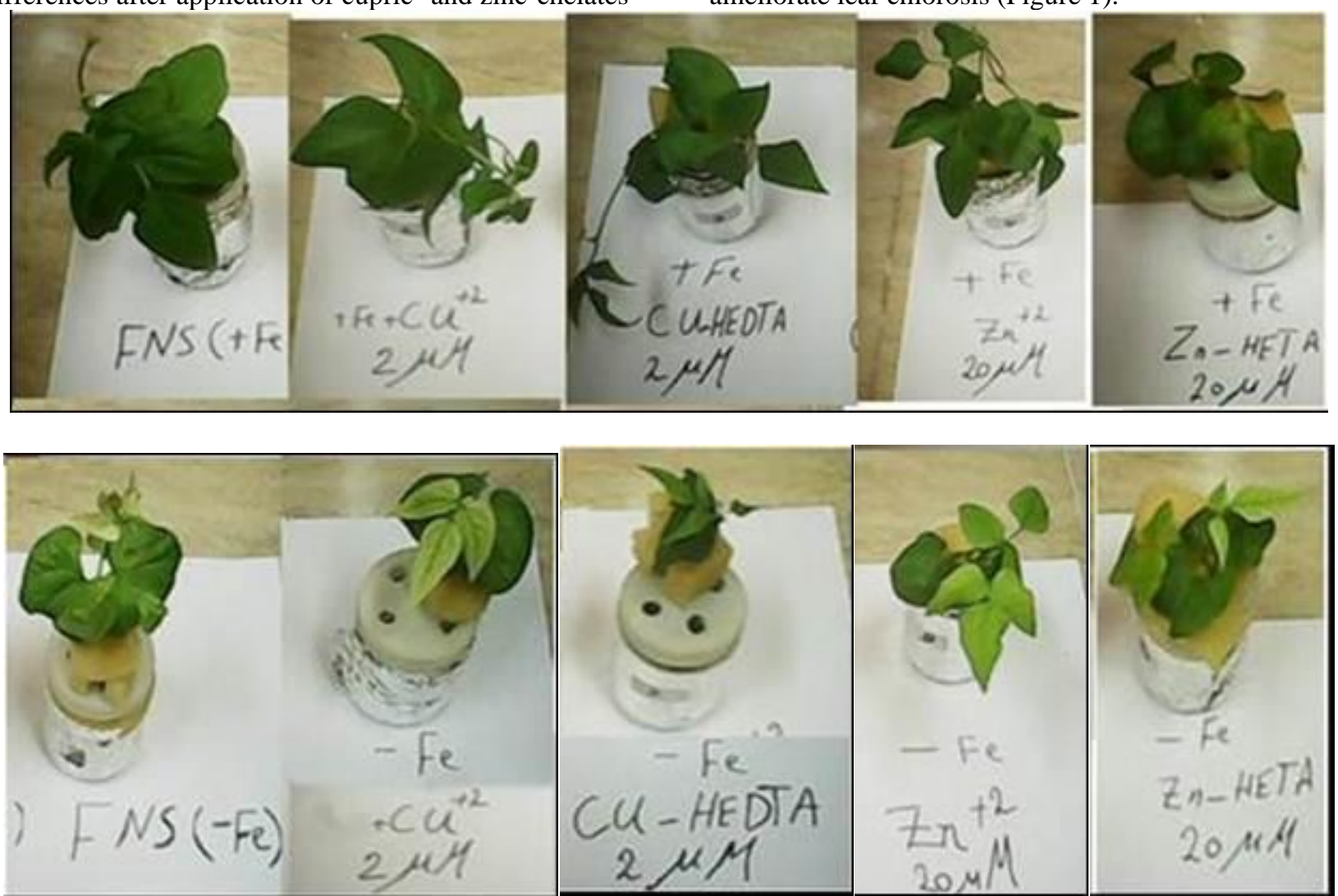

Figure 1. Effect of different chemical forms of $\mathrm{Cu}(2 \mu \mathrm{mol})$ and $\mathrm{Zn}(20 \mu \mathrm{mol})$ on symptoms of iron deficiency in phaseolus leaves.

The duration of the experiment might be not sufficient to remedy leaf chlorosis of phaseolus, treated with zincchelate. Other authors indicated that plant roots treated with zinc did not show fast response like copper (9). While, chelated copper of iron-deficient phaseolus improved chlorophyll biosynthesis in treated $\mathrm{Fe}$ deficient plants (Figure1).

\section{Root dry weights}

Depending on the chemical form of copper and zinc used in this experiment the decrease of root dry weight under conditions of iron-deficient was observed. Data presented in (Figure 2) indicate that the decrease was observed in root dry weight with morphological changes in Fe deficient plants. The concentration of $2 \mu \mathrm{M}$ cupric chelate showed a significant increase for dry weight of Fe-deficient phaseolus plants, as compared to the decrease of root growth weight at the same concentration of ionic copper. Cupric chelate improved the root growth and prevented the nutritional disorders and consequently, increased the uptake of nutrients by roots (16). These findings are in agreement with those obtained by $(15,28)$. It has been found that zinc application to maize crops enhances biomass production and plant zinc concentration $(28,36,38)$. 


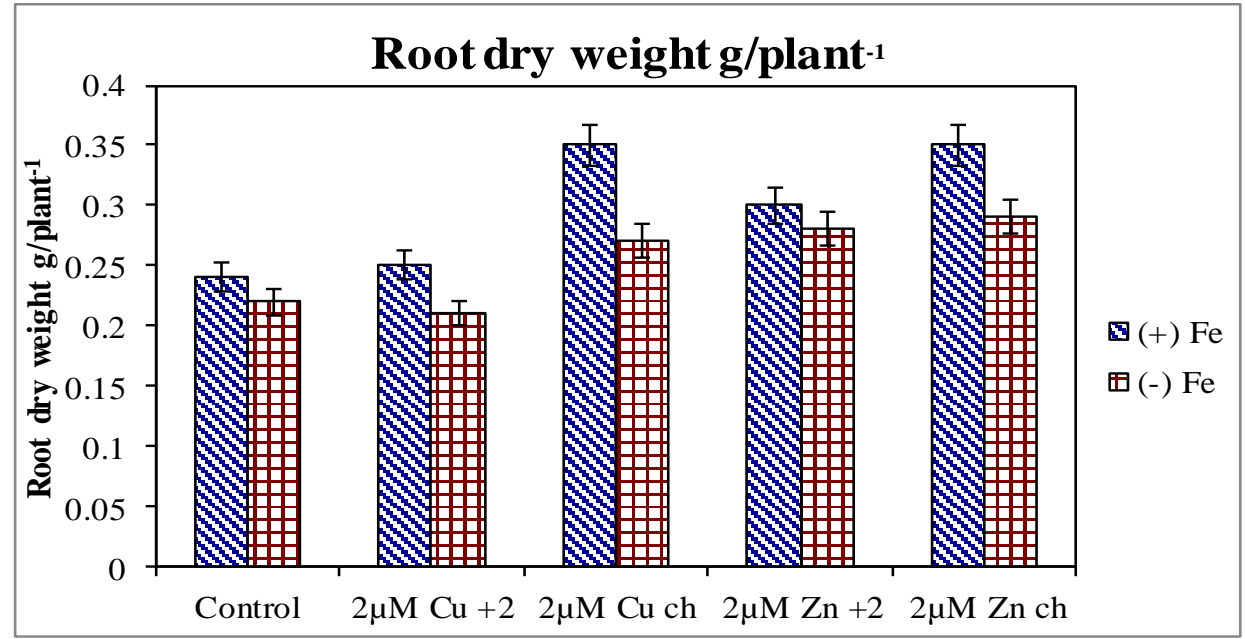

Figure 2. Effect of different chemical forms of $\mathrm{Cu}(2 \mu \mathrm{mol})$ and $\mathrm{Zn}(20 \mu \mathrm{mol})$ on dry weights

\section{Micronutrients uptake}

Data presented in (Figure 3) show that under iron feeding conditions $(+\mathrm{Fe})$ the presence of copper and $\mathrm{Zn}$ in the ionic form $\mathrm{Cu}^{+2}$ and $\mathrm{Zn}^{+2}$ or in Chelated form marked decreasing in $\mathrm{Fe}$ content. However under $\mathrm{Fe}$ deficient conditions plants showed increasing in $\mathrm{Fe}$ content in presence of $\mathrm{Cu}$ and $\mathrm{Zn}$ in chelated form or $\mathrm{Zn}$ in ionic form $\mathrm{Zn}^{+2}$.Zinc content shows the highest increment in the presence in of full nutrient solution $(+\mathrm{Fe})$ in the presence of ionic $\mathrm{Zn}{ }^{+2}$ or $\mathrm{Zn}$-chelated. The same trend was observed under iron deficient plants ($\mathrm{Fe}$ ).Whereas, Copper chelate increase the $\mathrm{Cu}$ content but under Fe deficient conditions. Whereas, copper content increase in presence of ionic $\mathrm{Cu}$ and both of copper and zinc chelated. This may be due to the role of chelation in the mechanism of metal uptake and translocation and metabolism in plants (16). Also may be due to the reactivity of copper ions to form stable complexes and to participate in root redox reactions such as proton release and $\mathrm{Fe} \mathrm{Ch}$ - reductase activity at the plasma membrane $(10,18,37)$.

\section{Pigments content}

The concentrations of photosynthetic pigment of phaseolus plants grown in the presence or absence of $\mathrm{Fe}$ are shown in (Table 1). In general the plants in deficient $\mathrm{Fe}$ resulted in a significant decrease in the chlorophyll (a) -chlorophyll (b) and chlorophyll $(\mathrm{a}+\mathrm{b})$ leaf content with the appearance of yellowing in new leaves (Figure 1). The addition of $2.0 \mu \mathrm{mol}$ copper metals or the addition of $20 \mu \mathrm{mol}$ zinc metal in the absence of iron led to a significant decrease in the content of chlorophyll with the appearance of pale yellowing in new leaves (Figure 1). The addition of $2.0 \mu \mathrm{M}$ or $20 \mu \mathrm{M}$ of $\mathrm{Cu}$-HEDTA Zn-HEDTA resulted in a significant increase in leaf content of chlorophyll A, B and T-Chl $(\mathrm{a}+\mathrm{b})$ compared to non-iron treatment. Zn HEDTA might improve the tolerance of phaseolus plants by restoring the main photosynthetic pigments. The similar results were reported by (29) in maize plants, from excessive ROS. $\mathrm{Cu}$ (II) HEDTA participates in the process of greening by remobilization of apoplastic and cellular iron pools (Figure1).In spite of very strong chlorosis invariant $(-\mathrm{Fe}+\mathrm{Cu})$ before treatment with $\mathrm{Cu}$ (II), HEDTA leaf greening started soon after application $\mathrm{Cu}$ and $\mathrm{Zn}$ HEDTA. Cu (II) HEDTA supply produced smaller, but still positive effect and Zn (II) HEDTA supply did not ameliorate leaf chlorosis (Figure 2). The duration of this experiment might be not sufficient to remedy leaf chlorosis of phaseolus, treated with zincchelate(9) 

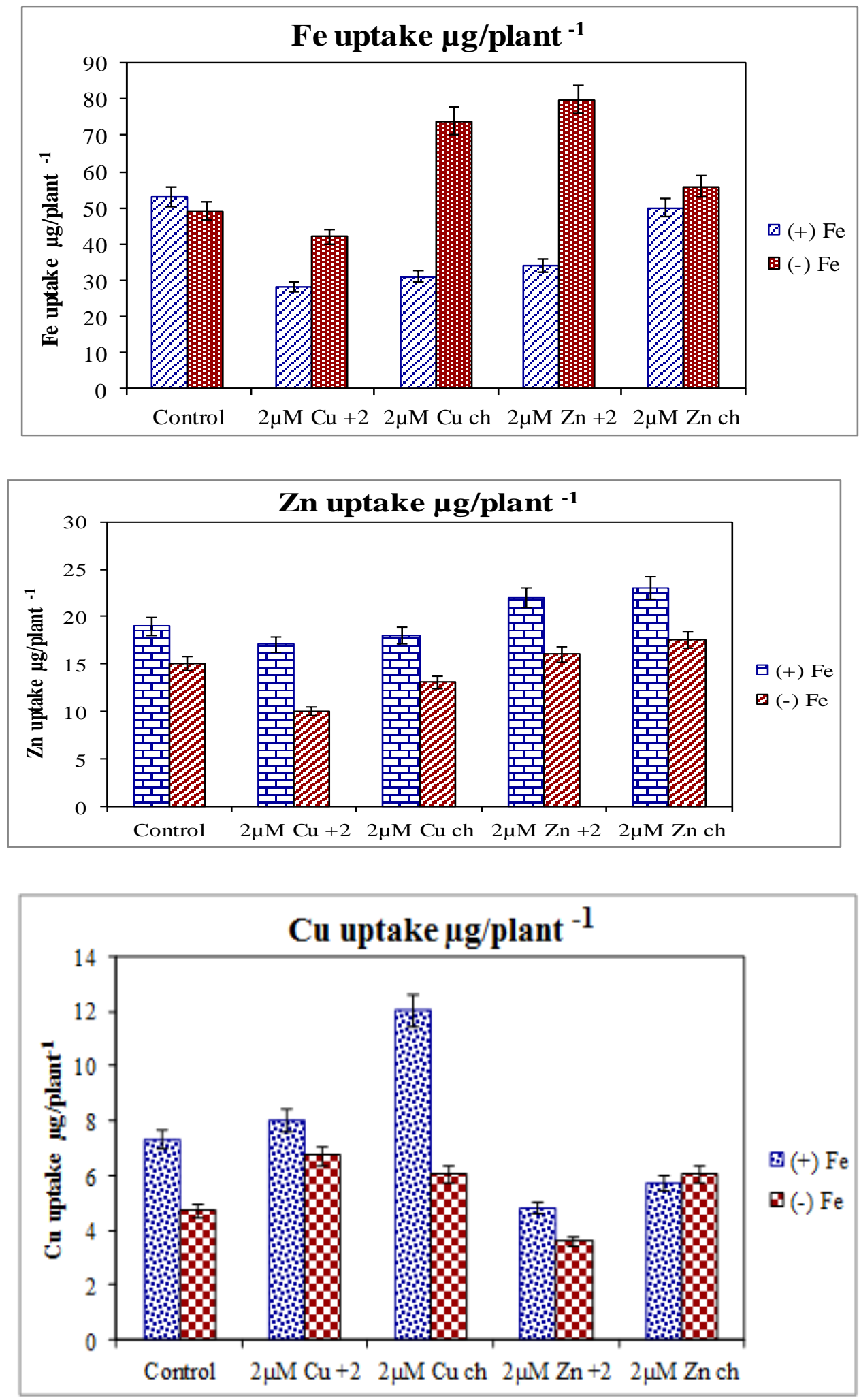

Figure 3. Effect of different chemical forms of $\mathrm{Cu}(2 \mu \mathrm{mol})$ and $\mathrm{Zn}(20 \mu \mathrm{mol})$ micronutrients uptake. 
Table 1. Effect of different chemical forms of $\mathrm{Cu}(2 \mu \mathrm{mol})$ and $\mathrm{Zn}(20 \mu \mathrm{mol})$ on chlorophyll (a),(b) and Total $(a+b)$ and antioxidant enzymes activity.

\begin{tabular}{|c|c|c|c|c|c|c|}
\hline & Variants & $\begin{array}{c}\text { Chla } \\
\text { mg/gfw }\end{array}$ & $\begin{array}{c}\text { Chlb } \\
\text { mg/gfw }\end{array}$ & $\begin{array}{c}\text { T-Chl(a+b) } \\
\mathrm{mg} / g f w\end{array}$ & $\begin{array}{c}\text { POD } \\
\text { EU/gfw }\end{array}$ & $\begin{array}{c}\text { SOD } \\
\mathrm{mg} / g f w\end{array}$ \\
\hline \multirow{6}{*}{$\mathrm{FNS}(+\mathrm{Fe})$} & Control & $1.436^{a}$ & $0.369^{a}$ & $1.809^{\mathrm{a}}$ & $176^{\mathrm{a}}$ & $31^{a}$ \\
\hline & $\mathrm{Cu}^{+2}$ & $1.120^{b}$ & 0.258 a & $1.38^{b}$ & $272^{b}$ & $28 a^{b}$ \\
\hline & Cu-ch & $1.980^{c}$ & $0.412^{c}$ & $2.392^{\mathrm{c}}$ & $79^{c}$ & $30^{b}$ \\
\hline & $\mathrm{Zn}^{+2}$ & $1.950^{c}$ & $0.412^{c}$ & $2.36^{c}$ & $133^{\mathrm{d}}$ & $34^{b}$ \\
\hline & Zn-ch & $0.996^{c}$ & $0.389^{b}$ & $1.39^{c}$ & $156^{\mathrm{e}}$ & $43^{\mathrm{c}}$ \\
\hline & LSD 0.05 & 0.20 & 0.049 & 0.14 & 4.44 & 3.81 \\
\hline \multirow{6}{*}{ FNS(-Fe) } & Control & $0.335^{a}$ & $0.260^{c}$ & $0.595^{\mathrm{a}}$ & $230^{\mathrm{a}}$ & $39^{a}$ \\
\hline & $\mathrm{Cu}^{+2}$ & $0.219^{b}$ & $0.210^{\mathrm{a}}$ & $0.429^{b}$ & $245^{c}$ & $34^{b}$ \\
\hline & $\mathrm{Cu}-\mathrm{ch}$ & $0.711^{c}$ & $0.430^{d}$ & $1.141^{c}$ & $116^{c}$ & $42^{\mathrm{ab}}$ \\
\hline & $\mathbf{Z n}^{+2}$ & $0.210^{d}$ & $0.248^{b}$ & $0.458^{d}$ & $220^{b}$ & $39^{\mathrm{a}}$ \\
\hline & Zn-ch & $0.780^{e}$ & $0.426^{c}$ & $1.206^{\mathrm{e}}$ & $97^{\mathrm{d}}$ & $44^{\mathrm{ab}}$ \\
\hline & LSD 0.05 & 0.13 & 0.041 & 0.11 & 3.57 & 4.40 \\
\hline
\end{tabular}

All values with the same letters are not significant differences at $\mathbf{p} \geq 0.05$

Antioxidant enzymes activities

Improvement of stress tolerance under Fe deficiency is often linked to an increase in activity of antioxidant enzymes which can result in an increase in antioxidant enzyme activities, which in turn protect plants from oxidative stress caused by Fe deficiency $(8,29)$. Data presented in (Table 1) shows that under normal conditions of $(+\mathrm{Fe})$ treatment presence of ionic $\mathrm{Cu}^{+2}$ significantly increased POD enzyme activity. However, SOD did not affect. While presence of Cu-HEDTA or Zn-HEDTA significantly decreased the activities of both enzymes. Since iron deficiency caused oxidative stress in phaseolus. POD activity showed remarkable increase under $\mathrm{Fe}$ deficiency (Table 1) which accordance with the results of (29). However, presence of $\mathrm{Cu}^{2+}$ showed marked increase in POD enzyme activity as compared with either control or (-Fe) treatment. Superoxide dismutase (SOD) is an important member of the cell-protective antioxidant system. This enzyme catalyzes the dismutation of the superoxide anion into $\mathrm{H}_{2} \mathrm{O}_{2}$ plus molecular oxygen $(26,34)$. Under Fe deficiency SOD activity significantly increased in leaves in the presence of Cu-HEDTA or Zn-HEDTA (Table 1). These increases resulted highly significant with respect to the control. Previous work demonstrated that the mRNA level of $\mathrm{Cu} / \mathrm{Zn}$-dependent SOD in Saccharomyces cerevisiae, as well as its activity, was reduced in cells grown in $\mathrm{Cu}$-deficient medium (39). Therefore, increased SOD activity in phaseolus indicates that this plant has the capacity to adjust to high levels of ROS by developing an antioxidant defense system. Therefore, our results are in agreement with the postulation that $\mathrm{Cu}$ plays an important role as a cofactor in SOD protein synthesis and/or protein stability. The increment of SOD activity may account for the increased accumulation of superoxide radicals $\left(\mathrm{O}^{-}{ }^{-}\right)$in iron-deficient leaves (37).

\section{Fe-Chelate reductase activity}

The Fe chelate reductase isolates from sufficient control and $\mathrm{Fe}$ deficiency phaseolus plants in presence of different forms of $\mathrm{Cu}$ and $\mathrm{Zn}$ have been characterized in (Table 2). Fe deficiency in plants is usually caused by low $\mathrm{Fe}$ availability in calcareous, high-pH soils (25). Fe deficiency produces several physiological responses at the root level (32). The existence in the roots of dicotyledonous plants of an obligatory Fe reduction step from $\mathrm{Fe}$ (III) to $\mathrm{Fe}$ (II) prior to $\mathrm{Fe}$ root uptake was demonstrated first by (13). The reduction of Fe (III) to $\mathrm{Fe}$ (II) is carried out by one or several specialized enzymes (s) located in the root cell plasma membrane (PM), the ferric-chelate reductase (s) (FCh-RA) $(\underline{12}, \underline{14})$. Data presented in (Table 2) show that Fe Ch.RA significantly increased under (-Fe) compared to $(+\mathrm{Fe})$ treatment. Presence of $\mathrm{Cu}$ in ionic form leads to a decrease in the activity of ferric-chelate reductase activity (Fe Ch.R activity, whereas a little increase was observed with $\mathrm{Cu}$-HEDTA under Fe sufficient

Level $(+\mathrm{Fe})$. Superior increase of Fe Ch.R activity has been observed in presence of ionic and chelated zinc under Fe sufficient conditions, due to (Fe III reductase) play a role as the receiver of electrons on the plasmid wall of the roots. Under Fe deficiency the treatment of $\mathrm{Cu}$ in ionic or chelated and ionic $\mathrm{Zn}$ form decreased the activity of Fe Ch.RA compared to control. While ZnHEDTA significantly increased the Fe Ch.R activity (Table2). Fe deficiency caused similar changes in the ferric reductase activities and demonstrated the presence of redox proteins with similar properties at PM. High activation of ferric reductase in the roots of Fe-deficient plants might be connected to the same extent with increased copper uptake under iron starvation $(19,22)$. The direct connection between enhanced cupric-chelate reduction and increased copper content in plant roots was observed. The considerable inhibitory effect of ionic copper on the plant root reducing capacity after creation of Fe deficiency confirmed previously obtained results by others $(3,28,33)$. The alteration of $\mathrm{RA}$ in Fedeficient plants was related to $\mathrm{pH}$ changes in the nutrient solutions during iron starvation and copper treatment. Application of ionic copper started to inhibit release of protons by roots of Fe-deficient plants from the first day of solution change (7) and this inhibition correlated with the high inhibition of FeChRA by ionic copper. At the same time chelated copper application stimulated the $\mathrm{H}+$ extrusion by the roots of Fe-deficient phaseolus plants. Enhanced acidification of the medium during iron starvation is important for the induction of 
and sustaining the high level of FeChRA in many plants because the enzyme is $\mathrm{pH}$ sensitive $(33,42)$. Thus, one of the possible explanations for the high inhibition of ferric-reduction by free copper ions in roots under $\mathrm{Fe}$ -

Table 2. Effect of different chemical forms of $\mathrm{Cu}(2 \mu \mathrm{mol})$ and $\mathrm{Zn}(20 \mu \mathrm{mol})$ on $\mathrm{Fe}$-Chelate reductase activity

\begin{tabular}{|c|c|c|}
\hline & Variants & Fe(III) HEDTA-RA \\
\hline \multirow[t]{5}{*}{ FNS(+Fe) } & Control & $0.265^{\mathrm{a}}$ \\
\hline & $2 \mu \mathrm{M} \mathrm{Cu} u^{+2}$ & $0.251^{\mathrm{a}}$ \\
\hline & 2uMC $\mu$ HEDTA & $0.270^{b}$ \\
\hline & $20 \mu \mathrm{M} \mathrm{Zn}^{+2}$ & $0.435^{\mathrm{a}}$ \\
\hline & 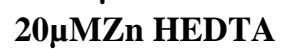 & $0.448^{b}$ \\
\hline LSD at 0.05 & & 0.038 \\
\hline \multirow[t]{5}{*}{ FNS(-Fe) } & Control & $2.760^{c}$ \\
\hline & $2 \mu \mathrm{M} \mathrm{Cu} u^{+2}$ & $1.450^{d}$ \\
\hline & 2uMC $\mu$ HEDTA & $1.920^{\mathrm{a}}$ \\
\hline & $20 \mu \mathrm{M} \mathrm{Zn}^{+2}$ & $1.550^{\mathrm{e}}$ \\
\hline & 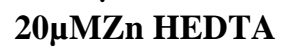 & $4.160^{b}$ \\
\hline LSD at 0.05 & & 0.378 \\
\hline
\end{tabular}

All values with the same letters are not significant differences at $\mathbf{p} \geq 0.05$ deficiency is the inhibition of proton release $(23,41$, 42). 


\section{CONCLUSION}

These results clarified that Ferric-chelate reductase at the plasma membrane of $\mathrm{Fe}$ - deficient Phaseolus roots showed a high activity in the presence of chelated copper. Another clarification for the limited effect of ionic copper on the behavior of Fe ChRA in iron-deficient roots is based on the hypothesis that copper might act as a potent scavenger of the superoxide radical, which was shown to simplify $\mathrm{Fe}$ chelate reduction at the plasma membrane.

\section{ACKNOWLEDGMENT}

This work was done in the frame of the cooperation between the National Research Centre (NRC) and Popov Institute for Plant Physiology Sofia-Bulgaria (Egyptian Academy of Science and TechnologyBulgarian Academy of Science). The authors thank Prof.Dr. Nadia Babalakova.It was supported by the Egypto -German Project "Micronutrient and other Plant Nutrition Problems "implemented by the National Research Centre (NRC) The project was supported by the Egyptian Academy of Science and Technology and the German Federal Ministry of Technical Cooperation (BMZ) through the German Agency for Technical Cooperation (GTZ).

\section{REFERENCES}

1.Al-Ansari, F. M. 2003. "Salinity tolerance during germination in two arid-land varieties of wheat (Triticum aestivum L.)." Seed Science and technology. 31.3: 597-603.

2.Akeredolu, I.A., B. E. Oguntona, C. Okafor and O.J.Osisanya. 2011. Iron, zinc and copper malnutrition among primary school children in Lagos, Nigeria. In Food Nutr Sci (Vol. 2, No. 10:1063-1070).

3.Alcántara, E., F. J., M. Romera, Cañete, and M. D. De la Guardia, 1994. Effects of heavy metals on both induction and function of root $\mathrm{Fe}$ (11) reductase in $\mathrm{Fe}$ deficient cucumber (Cucumis sativus L.) plants. Journal of Experimental Botany.45 (12): 1893-1898.

4.Amako, K., G. X., Chen, \& K.Asada. 1994. Separate assays specific for ascorbate peroxidase and guaiacol peroxidase and for the chloroplastic and cytosolic isozymes of ascorbate peroxidase in plants. Plant and Cell Physiology.35(3): 497-504.

5.Babalakova, N. \& D.Traykova. 2001. Copperinduced cupric-and ferric-chelate reduction by intact barley roots. Bulg. J. Plant Physiol. 27:

3-4.

6.Babalakova N, W.Schmidt 1996. Cupric chelate reduction by intact plant roots as an expression of constitutive and inducible redox systems. Comptes Rendus de l'Académie Bulgare des Sciences. 49:8790 .
7.Babalakova, N., S. Boycheva and S. Rocheva. 2005. Effects of Short-Term Treatment with Ionic And Chelated Copper On Membrane Redox-Activity Induction In Roots Of Iron-Deficient Cucumber Plants. Gen. Appl. Plant Physiology. 31(3-4):143155.

8.Babalakova NK, R.N, Kambourova, and S Rocheva. 2004. Iron deficiency impact on root redoxsystem activities and some antioxidant enzymes in cucumber cultivars. Comp Rend Acad Bulg Sci. 57:69-74.

9.Bartha, B., Z. Kolbert and L. Erdei. 2005. Nitric oxide production induced by heavy metals in Brassica juncea L. Czern and Pisum sativum L. Acta Biologica Szegediensis. 49(1-2): 9-12.

10.Boycheva SV, NK. Babalakova.2006. Reactions of root plasma membrane redox activities in irondeficient cucumber plants after application of ionic and chelated copper. Acta Biologica Szegediensis. 1;50 (1-2):49-54.

11.Bethke, P. C., Libourel, I. G., Reinöhl, V., \& Jones, R. L. (2006). Sodium nitroprusside, cyanide, nitrite, and nitrate break Arabidopsis seed dormancy in a nitric oxide-dependent manner. Planta, 223(4), 805-812.

12.Bienfait, H. F. 1985. Regulated redox processes at the plasmalemma of plant root cells and their function in iron uptake. Journal of bioenergetics and biomembranes. 17(2): 73-83.

13.Chaney RL, JC Brown, and LO. Tiffin. 1972. Obligatory reduction of ferric chelates in iron uptake by soybeans. Plant Physiology. 50(2): 208-213.

14.Cakmak, I., D.A. van de Wetering, H. Marschner, and H.F. Bienfait. 1987. Involvement of superoxide radical in extracellular ferric reduction by irondeficient bean roots. Plant Physiology. 85(1):310314.

15.Curie, C. and J.F. Briat .2003. Iron transport and signaling in plants. Annual Review of Plant Biology. 54(1):183-206.

16.Din, J., and T. J. Flowers.2002. "Effect of ABA seed pre-treatment on the response of wheat (Tritium aesitivum L.) to salinity, with special reference to plant growth, ion relations and protein patterns." Prospects for Saline Agriculture. Springer, Dordrecht: 145-153.

17.El-Fouly, M. M., Z. M. Mobarak, and Z. A. Salama. 2002. "Micronutrient foliar application control salination for horticultural productivity." Acta Hort . 573: 377-385.

18.Espen, L., M.Dell'Orto, P. De Nisi, and G. Zocchi. 2000. Metabolic responses in cucumber (Cucumis sativus L.) roots under Fe-deficiency: a 31 P-nuclear magnetic resonance in-vivo study. Planta.210 (6): 985-992. 
19.Guinn, G., and, H. E. Joham. 1963. Displacement of iron from ferric ethylenediaminetetraacetic acid and ferric hydroxyethylethylenediamine-triacetic acid by copper and zinc. Soil Science.95(2): 101-104.

20.Giannopolitis, C. N., and S. K. Ries.1977. Superoxide dismutases: I. Occurrence in higher plants. Plant physiology. 59(2): 309-314.

21.Hoagland, D. R., and D.I. Arnon. 1950. "The water-culture method for growing plants without soil." California Agr. Expt. Sta. Circ. 347.1: 32.

22.Herbik, A., A. Giritch, C. Horstmann R. Becker H. J., Balzer, H.Baumlein, and U. W. Stephan. 1996. Iron and copper nutrition-dependent changes in protein expression in a tomato wild type and the nicotianamine-free mutant chloronerva. Plant Physiology. 111(2): 533-540.

23.Holden MJ, T.J Crimmins and R.L Chaney 1995. $\mathrm{Cu}^{2+}$ reduction by tomato root plasma membrane vesicles." Plant physiology. 108.3: 1093-1098.

24.Lichthentaler, H. K. (1987). Chlorophyll and carotenoids-pigments of photosynthetic biomembranes,-In Colowick, SP., Kaplan, No (ed): Methods in Enzymology. Vol, 148: 350-382.

25.Lindsay, W. L., and Norvell, W. A. 1978. Development of a DTPA soil test for zinc, iron, manganese, and copper 1. Soil science society of America journal.42(3):421-428.

26.Rios, J., B. Blasco, L. Cervilla, M. Rosales, E. Sanchez-Rodriguez, L. Romero, and J. Ruiz. 2009. Production and detoxification of $\mathrm{H} 2 \mathrm{O} 2$ in lettuce plants exposed to selenium. Annals of Applied Biology. 154(1): 107-116.

27.Robinson N.J, C.M Proctor, E.L Connolly, M.L Guerinot. 1999. A ferric-chelate reductase for iron uptake from soils. Nature. 397:694-697.

28.Romera, F. J., E. Alcántara, and M. D. de, la Guardia.1997. Influence of bicarbonate and metal ions on the development of root $\mathrm{Fe}$ (III) reducing capacity by Fe-deficient cucumber (Cucumis sativus) plants. Physiologia Plantarum.101(1): 143-148.

29.Salama, Z. A. E. R., M. M. E Fouly and A. A. A Gaafar. 2015. Role of Chelated Zinc (Zn-HEDTA) Foliar Spray in Regulation Salt Stress in Maize Plants. Analele Universitatii din Oradea, Fascicula Biologie. 22 (1).

30.Sarath, G., P. C., Bethke, R., Jones, L. M. Baird, G. Hou, and R. B. Mitchell. 2006. Nitric oxide accelerates seed germination in warm-season grasses. Planta. 223(6):1154-1164.

31.Schmidt, W. 1994 "Reduction of extracytoplasmic acceptors by roots of Plantago lanceolata L. Evidence for enzyme heterogeneity." Plant Science. 100.2: 139-146.

32.Schmidt, W. 1999. Mechanisms and regulation of reduction-based iron uptake in plants. The New Phytologist.141(1): 1-26.
33.Schmidt W, M. Bartels, J. Tittel, and C. Fuhner. 1997. Physiological effects of copper on iron acquisition processes in Plantago. New Phytol. 135:659-666.

34.Ślesak, I., H. Ślesak, M.Libik, and Z.Miszalski, 2008. Antioxidant response system in the short-term post-wounding effect in Mesembryanthemum crystallinum leaves. Journal of plant physiology. 165(2): 127-137.

35.Snedecore, W.C. and W.G. Cochran.1980.Statistical Methods, 7th ed.The Iowa State Univ. Press, Ames, Iowa, USA.

36.Subbaiah, L. V., T. N. V. K. V., Prasad, T. G., Krishna, P., Sudhakar, B. R., Reddy, and B. R., Pradeep, T. 2016. Novel effects of nanoparticulate delivery of zinc on growth, productivity, and zinc biofortification in maize (Zea mays L.). Journal of agricultural and food chemistry. 64 (19): 3778-3788.

37.Sun, B. Jing, K. Chen, L. Song, F. Chen, and L. Zhang. 2007. Protective effect of nitric oxide on iron deficiency-induced oxidative stress in maize (Zea mays). Journal of plant physiology. 164(5): 536-543. 38.Taylor, G. J. and C. D. Foy. 1985. Differential uptake and toxicity of ionic and chelated copper in Triticum aestivum. Canadian Journal of Botany. 63(7): 1271-1275.

39. Thiele, D. J. 1992. Metal-regulated transcription in eukaryotes. Nucleic acids research. 20(6): 1183.

40.Zhang, X., D. Zhang, W. Sun, and T. Wang. 2019. The Adaptive Mechanism of Plants to Iron Deficiency via Iron Uptake, Transport, and Homeostasis. International journal of molecular sciences. 20(10): 2424.

41.Weger, H. G. 1999. Ferric and cupric reductase activities in the Chlamydomonas reinhardtii: experiments: using iron-limited chemostats. Planta.207 (3):377-384.

42. Wei, L. C., R. H., Loeppert, and W. R. Ocumpaugh. 1997. Fe-deficiency stress response in Fe-deficiency resistant and susceptible subterranean clover: the importance of induced $\mathrm{H}+$ release. Journal of Experimental Botany. 48.2: 239- 
